Tab. 2. Zasoby kapitałowe

\begin{tabular}{|c|c|c|c|c|c|c|c|c|c|c|c|c|}
\hline \multirow{3}{*}{$\begin{array}{l}\text { Grupy } \\
\text { firm }\end{array}$} & \multicolumn{10}{|c|}{ Elementy skali oceny } & \multirow{3}{*}{$\begin{array}{c}\text { Razem } \\
\text { liczba } \\
\text { odpowiedzi }\end{array}$} & \multirow{3}{*}{$\begin{array}{c}\text { Ogółem } \\
\text { liczba } \\
\text { odpowiedzi }\end{array}$} \\
\hline & \multicolumn{2}{|c|}{\begin{tabular}{|c|} 
Zasadnicza \\
siła
\end{tabular}} & \multicolumn{2}{|c|}{\begin{tabular}{|c|} 
Mało \\
istotna sila
\end{tabular}} & \multicolumn{2}{|c|}{$\begin{array}{c}\text { Czynnik } \\
\text { neutralny }\end{array}$} & \multicolumn{2}{|c|}{$\begin{array}{l}\text { Mało istot- } \\
\text { na słabość }\end{array}$} & \multicolumn{2}{|c|}{$\begin{array}{l}\text { Główna } \\
\text { słabość }\end{array}$} & & \\
\hline & $\begin{array}{c}\text { Licz- } \\
\text { ba } \\
\text { odp. }\end{array}$ & $\%$ & $\begin{array}{c}\text { Licz- } \\
\text { ba } \\
\text { odp. }\end{array}$ & $\%$ & $\begin{array}{c}\text { Licz- } \\
\text { ba } \\
\text { odp. }\end{array}$ & $\%$ & $\begin{array}{c}\text { Licz- } \\
\text { ba } \\
\text { odp. }\end{array}$ & $\%$ & $\begin{array}{c}\text { Licz- } \\
\text { ba } \\
\text { odp. }\end{array}$ & $\%$ & & \\
\hline Wieś & 2 & 11,1 & 2 & 11,1 & 1 & 5,5 & 2 & 22,3 & 9 & 50,0 & 18 & 47 \\
\hline Miasto & 0 & 0,0 & 9 & 31,0 & 2 & 6,9 & 6 & 20,7 & 12 & 41,4 & 29 & \\
\hline $\begin{array}{l}\text { Utworzone } \\
\text { do } 1992 \mathrm{r} \text {. }\end{array}$ & 1 & 4,5 & 5 & 22,7 & 1 & 4,5 & 3 & 13,5 & 12 & 63,8 & 22 & 47 \\
\hline $\begin{array}{l}\text { Utworzone } \\
\text { od } 1993 \mathrm{r} \text {. }\end{array}$ & 1 & 4,0 & 7 & 28,0 & 2 & 8,0 & 6 & 24,0 & 9 & 36,0 & 25 & \\
\hline Produkcyjne & 1 & 5,4 & 7 & 36,8 & 1 & 5,4 & 4 & 21,1 & 6 & 31,3 & 19 & 46 \\
\hline Handlowe & 1 & 8,4 & 3 & 25,0 & 2 & 16,6 & 3 & 25,0 & 3 & 25,0 & 12 & \\
\hline Usługowe & 1 & 6,7 & 0 & 0,0 & 1 & 6,7 & 3 & 20,0 & 11 & 66,6 & 15 & \\
\hline
\end{tabular}

Źródło: badania własne.

sytuacji ekonomicznej. Inwestycje w budynki, maszyny i urządzenia dowodzą chęci dalszego prowadzenia przedsiębiorstwa.

Dla 22,2\% firm położonych na obszarach wiejskich i 31,0\% prowadzących działalność gospodarczą w mieście zasoby kapitałowe w opinii badanych respondentów (byli to właściciele lub kierownicy badanych przedsiębiorstw) stanowiły mocny aspekt ich działalności gospodarczej

W przypadku podziału firm ze względu na dotychczasowy okres funkcjonowania (utworzone do $1992 \mathrm{r}$. oraz utworzone od 1993 r.) odpowiednio w $27,2 \%$ i $32,0 \%$ badanych podmiotów zasoby kapitałowe zostały uznane za ich mocną stronę. W przypadku podziału według rodzaju prowadzonej działalności gospodarczej charakterystyczna jest względnie wysoka liczba wskazań na zasoby kapitałowe w przedsiębiorstwach produkcyjnych $(42,2 \%)$, natomiast niewielka w firmach usługowych $(6,7 \%)$. Reasumując powyższe rozważania należy także wyraźnie podkreślić (tab. 2) małą liczbę odpowiedzi, określających zasoby kapitałowe badanych firm jako ich zasadnicza siłę.

Następstwem niskich ocen zasobów kapitałowych badanych przedsiębiorstw jest duża liczba wskazań, które określaja je jako słaba stronę ich sytuacji. Szczególnie niskie oceny zasobów kapitałowych były w przypadku przedsiębiorstw prowadzacych działalność na obszarach wiejskich (72,3\% wskazań), firm utworzonych do 1992 r. (77,3\%) oraz firm prowadzących działalność usługowa (86,6\%). Wśród tych ostatnich ocen zwraca również uwage fakt, że w podanych danych liczbowych określających słabości dominują wskazania określone w niniejszym opracowaniu jako „główna słabość". Podsumowując analizę zasobów kapitałowych należy stwierdzić, że udział odpowiedzi wskazujacych je jako mocną stronę jest zdecydowanie niższy w stosunku do wskazań określających ten czynnik jako słabą stronę (pomijamy w tym miejscu element skali oceny określony jako czynnik neutralny, ponieważ jego znaczenie miało we wskazaniach charakter marginalny ${ }^{3)}$.

\section{Płynność finansowa}

rawidłowe funkcjonowanie przedsiębiorstwa w dużym stopniu zależy od posiadanych środków na bieżące finansowanie prowadzonej działalności gospodarczej. W klasycznym rachunku wyników wszystkie należności finansowe traktowane są jednakowo. Forma i czas płatności nie są brane pod uwagę. Następuje „rozkojarzenie” terminów wpływów gotówki oraz zapadajacych terminów płatności na rzecz wierzycieli. Dlatego też poziom należności podlega najczęściej istotnym zmianom w czasie. Problemy te sa rozwiązywane na gruncie teorii płynności finansowej. Pod pojęciem tym według Bienia ${ }^{4)}$ należy rozumieć zdolność do terminowego regulowania przez firmę zobowiązań. Ryzyko utraty płynności finansowej oznacza utratę zdolności do uzyskiwania kredytów i pożyczek. Powstaje ono nie tylko w przypadku pojawiania się strat, ale również wówczas, kiedy zostanie naruszona równowaga między terminami wpływu gotówki. Między majątkiem obrotowym a bieżącymi zobowiązaniami istnieja odpowiednie, chociaż bardzo zróżnicowane relacje. Dotyczą one sum, jak również terminów upłynniania pozycji aktywów i spłaty poszczególnych zobowiązań.

W badanych firmach dominujace znaczenie miały wskazania określające płynność finansową jako ich mocna stronę. W przypadku firm produkcyjnych stanowiły one $83,4 \%$ ich całkowitej liczby (był to najwyższy udział), natomiast dla przedsiębiorstw prowadzących działalność gospodarcza na obszarach wiejskich ukształtował się na poziomie $53,0 \%$. Sa to wartości skrajne i między nimi mieściły się wskaźniki udziału dla 5 pozostałych wariantów oceny płynności finansowej. Informacje podane w tabeli 3 jednoznacznie pokazują, że płynność finansowa stanowi według opinii badanych właścicieli (kierowników) firm mocny punkt działalności tych przedsiębiorstw.

Jednak pogłębiona analiza danych liczbowych z tabeli 3 wyraźnie pokazuje, że w ramach podanych wyżej ocen zdecydowanie większy udział mają wskazania na element oceny określony jako „istotna siła”, 
Tab. 3. Płynność finansowa

\begin{tabular}{|c|c|c|c|c|c|c|c|c|c|c|c|c|}
\hline \multirow{3}{*}{$\begin{array}{l}\text { Grupy } \\
\text { firm }\end{array}$} & \multicolumn{10}{|c|}{ Elementy skali oceny } & \multirow{3}{*}{$\begin{array}{c}\text { Razem } \\
\text { liczba } \\
\text { odpowiedzi }\end{array}$} & \multirow{3}{*}{$\begin{array}{c}\text { Ogółem } \\
\text { liczba } \\
\text { odpowiedzi }\end{array}$} \\
\hline & \multicolumn{2}{|c|}{$\begin{array}{c}\text { Zasadnicza } \\
\text { sila }\end{array}$} & \multicolumn{2}{|c|}{$\begin{array}{c}\text { Istotna } \\
\text { sila }\end{array}$} & \multicolumn{2}{|c|}{$\begin{array}{c}\text { Czynnik } \\
\text { neutralny }\end{array}$} & \multicolumn{2}{|c|}{$\begin{array}{l}\text { Mało istot- } \\
\text { na słabość }\end{array}$} & \multicolumn{2}{|c|}{$\begin{array}{l}\text { Główna } \\
\text { słabość }\end{array}$} & & \\
\hline & $\begin{array}{c}\text { Licz- } \\
\text { ba } \\
\text { odp. }\end{array}$ & $\%$ & $\begin{array}{c}\text { Licz- } \\
\text { ba } \\
\text { odp. }\end{array}$ & $\%$ & $\begin{array}{c}\text { Licz- } \\
\text { ba } \\
\text { odp. }\end{array}$ & $\%$ & $\begin{array}{c}\text { Licz- } \\
\text { ba } \\
\text { odp. }\end{array}$ & $\%$ & $\begin{array}{c}\text { Licz- } \\
\text { ba } \\
\text { odp. }\end{array}$ & $\%$ & & \\
\hline Wieś & 2 & 11,8 & 7 & 41,2 & 4 & 23,5 & 1 & 5,9 & 3 & 17,6 & 17 & \\
\hline Miasto & 4 & 14,3 & 13 & 46,4 & 4 & 14,3 & 6 & 21,4 & 1 & 3,6 & 28 & 45 \\
\hline $\begin{array}{l}\text { Utworzone } \\
\text { do } 1992 \mathrm{r} \text {. }\end{array}$ & 2 & 9,5 & 10 & 47,7 & 3 & 14,3 & 4 & 19,0 & 2 & 9,5 & 21 & 46 \\
\hline $\begin{array}{l}\text { Utworzone } \\
\text { od } 1993 \text { r. }\end{array}$ & 5 & 20,0 & 10 & 40,0 & 5 & 20,0 & 3 & 12,0 & 2 & 8,0 & 25 & \\
\hline Produkcyjne & 2 & 11,1 & 6 & 33,3 & 3 & 16,7 & 5 & 27,8 & 2 & 11,1 & 18 & 45 \\
\hline Handlowe & 1 & 8,3 & 9 & 75,1 & 0 & 0,0 & 1 & 8,3 & 1 & 8,3 & 12 & \\
\hline Usługowe & 3 & 20,0 & 5 & 33,3 & 5 & 33,3 & 1 & 6,7 & 1 & 6,7 & 15 & \\
\hline
\end{tabular}

Źródło: badania własne.

a więc nieco słabszy. Upoważnia to do sformułowania poglądu, że w dokonanych ocenach płynności finansowej 47 badanych przedsiębiorstw podchodzi się w sposób dosyć ostrożny do tego problemu.

Marginesowe znaczenie mają oceny typu „zasadnicza siła”. Ma miejsce wyraźna dominacja ocen o mniejszej skali mocnych akcentów. Należy również zasygnalizować dużą liczba wskazań na płynność finansową jako istotną siłę w przedsiębiorstwach handlowych.

W zasadzie można uznać, że udział ocen traktujących płynność finansową jako czynnik neutralny $\mathrm{w}$ funkcjonowaniu badanych przedsiębiorstw ma zdecydowanie mniejsze znaczenie w porównaniu z omówionymi powyżej ocenami. Jedynie w przypadku przedsiębiorstw świadczących usługi wskaźnik ten wyniósł $33,3 \%$.

Płynność finansowa jako słaba strona badanych przedsiębiorstw oceniana była w zdecydowanie mniejszym zakresie niż jako mocna strona. Najbardziej ne- gatywnie została oceniona w przypadku firm produkcyjnych (łącznie 38,9\% wskazań), natomiast w przypadku pozostałych przedsiębiorstw udział wskazań mieścił się w granicach od 13,4\% (najmniejszy udział ocen negatywnych) do 28,5\% (najwyższy).

\section{Rentowność prowadzenia działalności gospodarczej}

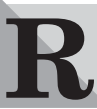

entowność to jeden z najważniejszych mierników oceny efektywności gospodarowania w przedsiębiorstwie. Na efektywność gospodarowania patrzymy zwykle z punktu widzenia korzyści dla danego przedsiębiorstwa oraz korzyści dla prowadzącego. Możliwa jest również analiza tego zjawiska z punktu widzenia interesów społeczeństwa. Rentowność wyraża stopień opłacalności angażowanych bądź zużywanych w przedsiębiorstwie zasobów czynników wytwórczych. Może być obliczana jedynie na podstawie danych ujętych wartościowo, ponieważ

Tab. 4. Rentowność prowadzenia działalności gospodarczej

\begin{tabular}{|c|c|c|c|c|c|c|c|c|c|c|c|c|}
\hline \multirow{3}{*}{$\begin{array}{l}\text { Grupy } \\
\text { firm }\end{array}$} & \multicolumn{10}{|c|}{ Elementy skali oceny } & \multirow{3}{*}{$\begin{array}{c}\text { Razem } \\
\text { liczba } \\
\text { odpowiedzi }\end{array}$} & \multirow{3}{*}{$\begin{array}{c}\text { Ogółem } \\
\text { liczba } \\
\text { odpowiedzi }\end{array}$} \\
\hline & \multicolumn{2}{|c|}{$\begin{array}{c}\text { Zasadnicza } \\
\text { siła }\end{array}$} & \multicolumn{2}{|c|}{$\begin{array}{c}\text { Mało } \\
\text { istotna sila }\end{array}$} & \multicolumn{2}{|c|}{$\begin{array}{c}\text { Czynnik } \\
\text { neutralny }\end{array}$} & \multicolumn{2}{|c|}{$\begin{array}{l}\text { Mało istot- } \\
\text { na słabość }\end{array}$} & \multicolumn{2}{|c|}{$\begin{array}{l}\text { Główna } \\
\text { słabość }\end{array}$} & & \\
\hline & $\begin{array}{c}\text { Licz- } \\
\text { ba } \\
\text { odp. }\end{array}$ & $\%$ & $\begin{array}{l}\text { Licz- } \\
\text { ba } \\
\text { odp. }\end{array}$ & $\%$ & $\begin{array}{c}\text { Licz- } \\
\text { ba } \\
\text { odp. }\end{array}$ & $\%$ & $\begin{array}{c}\text { Licz- } \\
\text { ba } \\
\text { odp. }\end{array}$ & $\%$ & $\begin{array}{l}\text { Licz- } \\
\text { ba } \\
\text { odp. }\end{array}$ & $\%$ & & \\
\hline Wieśs & 2 & 11,2 & 4 & 22,4 & 1 & 5,6 & 7 & 38,4 & 4 & 22,4 & 18 & 46 \\
\hline Miasto & 1 & 3,6 & 9 & 32,1 & 1 & 3,6 & 16 & 57,1 & 1 & 3,6 & 28 & \\
\hline $\begin{array}{l}\text { Utworzone } \\
\text { do } 1992 \mathrm{r} \text {. }\end{array}$ & 1 & 4,5 & 5 & 22,7 & 1 & 4,5 & 12 & 63,8 & 1 & 4,5 & 22 & 47 \\
\hline $\begin{array}{l}\text { Utworzone } \\
\text { od } 1993 \mathrm{r} \text {. }\end{array}$ & 3 & 12,0 & 6 & 24,0 & 2 & 8,0 & 11 & 44,0 & 3 & 12,0 & 25 & \\
\hline Produkcyjne & 3 & 15,0 & 5 & 25,0 & 0 & 0,0 & 10 & 50,0 & 2 & 10,0 & 20 & 47 \\
\hline Handlowe & 1 & 9,1 & 3 & 27,2 & 2 & 18,2 & 4 & 36,4 & 1 & 9,1 & 11 & \\
\hline Usługowe & 0 & 0,0 & 4 & 25,0 & 0 & 0,0 & 9 & 62,5 & 2 & 12,5 & 16 & \\
\hline
\end{tabular}

Źródło: badania własne. 
w miernikach technicznych lub techniczno-produkcyjnych nie można ująć jedną liczbą całości nakładów i całości produkcji.

Podobnie jak w przypadku trzech wyżej omówionych czynników finansowych charakteryzujących zjawiska finansowe w badanych przedsiębiorstwach, również i w przypadku wskaźnika rentowności uwzględniamy 3 powyższe kryteria podziału analizowanych przedsiębiorstw. Tabela 4 przedstawia wyniki szczegółowych obliczeń. Dla 33,6\% przedsiębiorstw położonych na obszarach wiejskich oraz $35,7 \%$ prowadzacych działalność gospodarczą w mieście rentowność prowadzonej działalności gospodarczej została uznana przez właścicieli (kierowników) badanych firm za mocną stronę. W przypadku podziału firm ze względu na dotychczasowy okres ich funkcjonowania wskaźnik ten ukształtował się odpowiednio na poziomie: dla starszych firm $27,2 \%$, natomiast młodszych $36,0 \%$. $\mathrm{Z}$ kolei dla firm produkcyjnych, handlowych i usługowych wyniósł odpowiednio: 40,0\%, 36,3\% i 25,0\%.

Przedstawione powyżej dane liczbowe jednoznacznie pokazują, że poziom rentowności w opinii respondentów nie jest czynnikiem, który wzmacnia pozycje firmy na rynku. Charakterystyczne jest, że w ocenach dominujące znaczenie mają (tab. 4) wskazania rentowności w przyjętej 5-punktowej skali jako mało istotnej siły. Na podstawie zaprezentowanych danych liczbowych można bez trudu wnioskować, że dominowały wskazania określające rentowność prowadzonej działalności gospodarczej jako słabą stronę funkcjonowania danego przedsiębiorstwa. Dla przedsiębiorstw położonych tak na wsi, jak i w mieście wskaźnik ten wynosił odpowiednio $60,8 \%$ i $60,7 \%$, utworzonych do 1992 r. oraz od 1993 r. odpowiednio 68,3\% i 56,0\%. Przedsiębiorstwa usługowe uznane były za najmniej rentowne $(75,0 \%$ wskazań). Dla firm handlowych wskaźnik ten wyniósł 45,5\%, natomiast produkcyjnych $60,0 \%$. W ich ramach dominujące znaczenie miały wskazania określające rentowność jako mało istotną siłe funkcjonowania tych przedsiębiorstw. Oznacza to, że podobnie jak w przypadku charakteryzowanej na początku mocnej strony również i tutaj ma miejsce raczej bardziej łagodna ocena tego czynnika finansowego.

\section{Podsumowanie i wnioski}

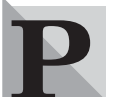

rzeprowadzone badania jednoznacznie wykazały, że czynniki finansowe stanowią istotny problem w działalności gospodarczej przedsiębiorstw. Uwzględnione w analizie 3 parametry finansowe, tj. zasoby kapitałowe, płynność finansowa oraz rentowność prowadzenia działalności gospodarczej objaśniły główne słabości w badanych firmach. Podstawowe wnioski wynikające $\mathrm{z}$ analizy zostały sformułowane następująco:

- Zasoby kapitałowe podmiotów gospodarczych w Polsce stanowią słabą stronę ich działalności. W badanych firmach jedynie w ok. 30\% zostały uznane za mocny punkt ich działalności. Tak więc wyniki przeprowadzonych badań jednoznacznie potwierdziły prezentowaną w literaturze prawidłowość. Z punktu widzenia racjonalizacji działań gospodarczych oznacza to, że konieczne są decyzje na administracyjnych i gospodarczych szczeblach zarządzania gospodarką zwiększające możliwości zasilania kapitałowego przedsiębiorstw, szczególnie w obszarach środkowowschodniej Polski. Również szerokie działania w tym zakresie powinny podejmować banki komercyjne na rzecz promocji swoich produktów.

- W dużej grupie badanych przedsiębiorstw płynność finansowa została oceniona jako „mało istotna siła”. W regionie, w którym prowadzone były badania (są to obszary środkowowschodniej Polski, a więc tereny o relatywnie niskim poziomie rozwoju gospodarczego) pojęcie płynności finansowej jest jednym z mniej upowszechnionych w praktyce gospodarczej terminów ekonomicznych. Szczególnie dotyczy to małych firm, które dominowały w badanej grupie. Dlatego też wyniki badań upoważniają do wyrażenia poglądu, że uwaga powinna być skoncentrowana na działaniach edukacyjnych w zakresie finansów.

- Stopień rentowności prowadzonej działalności gospodarczej oceniony został na poziomie ok. 30\% dla wszystkich uwzględnionych wariantów grup badanych przedsiębiorstw, przy czym dominujące znaczenie miały wskazania określone jako „mało istotna siła”. Oznacza to, że rentowność badanych firm kształtowała się, zdaniem respondentów, na relatywnie niskim poziomie. dr Kazimierz Łęczycki

Zakład Agrobiznesu

PRZYPISY

Akademii Podlaskiej w Siedlcach

1) B. OLZACKA, R. PAŁCZYŃSKA- GOŚCINIAK, Leksykon zarzadzania finansami, ODDK, Gdańsk 1998, s. 92.

2) Uogólnianie zjawisk ekonomicznych na podstawie zbyt mało liczebnej próby badawczej jest obarczone pewnym ryzykiem. Wydaje sięjednak, że podjęta w niniejszym opracowaniu problematyka jest na tyle ważna $i$ istotna, że sformułowane wnioski posiadaja istotna wartość poznawczą.

3) Szczegółowe wyniki obliczeń, wyodrębniające 5 elementów skali oceny przedstawia tabela 1 , natomiast w części opisowej opracowania dokonujemy sumowania „zasadniczej siły” oraz „mało istotnej siły” i stosujemy określenie „mocna strona”. Podobnie czynimy z określeniem „mało istotna słabość” oraz „główna słabość”, które nazywamy „słabą stroną" przedsiębiorstwa (taki sposób postępowania to oczywiście wpływ nazewnictwa stosowanego w bardzo popularnej u nas metodzie analizy strategicznej SWOT)

4) W. BIEN, Zarzadzanie finansami przedsiębiorstwa, Difin, Warszawa 1996, s. 15.

\section{BIBLIOGRAFIA}

[1] BIEŃ W., Zarzqdzanie finansami przedsiębiorstwa, Difin, Warszawa 1996.

[2] CHADAM J.,Przeptywy środków pieniężnych w spótkach kapitałowych - wyniki badań, „Przegląd Organizacji” 2003, nr 5 .

[3] KURTYS E. (red.), Analiza ekonomiczna przedsiębiorstwa, Wydawnictwo AE we Wrocławiu, Wrocław 1996.

[4] LICHTARSKI J. (red.), Podstawy nauki o przedsiebiorstwie, Wydawnictwo AE we Wrocławiu, Wrocław 1995.

[5] ŁĘCZYCKI K. (red.), Przedsiębiorstwo w agrobiznesie, Wydawnictwo Akademii Podlaskiej, Siedlce 2003.

[6] OLZACKA B., PAŁCZYŃSKA-GOŚCINIAK R., Leksykon zarzadzania finansami, ODDK, Gdańsk 1998.

[7] SIERPIŃSKA M., JACHNA T., Ocena przedsiebiorstwa wedtug standardów światowych, Wydawnictwo Naukowe PWN, Warszawa 1994.

[8] STRUŻYNA J., Obrazy kapitału catkowitego firmy, „Organizacja i Kierowanie" 2002, nr 1.

[9] TKACZUK M., DEBNIEWSKA M., Analiza ekonomiczna przedsiębiorstwa, Wydawnictwo ART, Olsztyn 1998.

[10] ZBROJA A., Sektor matych $i$ średnich przedsiębiorstw $w$ okresie transformacji gospodarczej - zmiany strukturalne, „Przegląd Organizacji” 2003, nr 7/8. 